\title{
CINEMA DO TEMPO, PROFUNDIDADE DE CAMPO E A METAFÍSICA DA MEMÓRIA EM DELEUZE ${ }^{1}$
}

\author{
Ana Carolina Gomes Araújo (IFTM) ${ }^{2}$ \\ carol.gomescg@gmail.com
}

Resumo: Em Imagem-tempo Deleuze quando do quarto comentário a Bergson fala em cinema do tempo remetendo a Orson Welles e ao filme Cidadão Kane. O cinema do tempo é apresentado a partir de três caracteres de um tempo não cronológico. Deleuze aponta para uma condição do cinema do tempo ao propor a substituição de uma vista pragmática longitudinal por uma visão ótica, vertical, em profundidade. A profundidade de campo é trabalhada enquanto um elemento conceitual no trato de uma metafísica da memóriaem diálogo com as bases do cinema moderno, nesse sentido, os três caracteres de um tempo não cronológico e a inserção de uma nova relação entre tempo e espaço no cinema são constituintes de uma imagem tempo direta cujo problema filosófico perpassa a inserção do movimento no pensamento. $\mathrm{O}$ encontro do quarto comentário em Imagem-tempo com o primeiro comentário a Bergson em Imagem-movimento é o percurso para compreender a importância da profundidade de campo. Assimo cinema do tempo de Welles é entendido como o cinema de uma metafísica da memória a partir de duas fontes: o esforço atual de evocação para suscitar a imagemlembrança e a exploração das zonas virtuais de passado para encontrar a imagem-lembrança.

Palavras-chave: cinema; tempo; Deleuze; profundidade de campo; Bergson.

\section{INTROdUÇÃO: PERCEPÇÃO DE MOVIMENTOE PERCEPÇÃO NATURAL NA CONSTITUIÇÃO DA IMAGEM}

\section{Cinema do tempo é uma definição utilizada por Deleu-}

\footnotetext{
${ }^{1}$ Recebido: 08-01-2018/ Aceito: 30-04-2018/ Publicado on-line: 05-10-2020.

${ }^{2}$ É professora efetiva no Instituto Federal de Educação, Ciência e Tecnologia do Triângulo Mineiro (IFTM), Uberlândia, MG, Brasil.
} 
ze em 1985 pontualmente remetendo ao filme de Orson Welles de 1941, Cidadão Kane. Aqui nos interessa compreender as articulações do autor ao operar uma aproximação entre a técnica de composição fílmica conhecida como profundidade de campo e as teses sobre Bergson que são desenvolvidas por Deleuze nos seus livros sobre cinema. Dois são os horizontes do filósofo, o cinema e as particularidades enquanto produção artística que pensa o mundo através de imagens e a filosofia que pensa o mundo através de concei$\operatorname{tos}^{3}$.Nesse sentido, compreender o cinema do tempo exige acompanhar um trajeto do autor na sua relação com a sétima arte, bem como a escolha por uma aliança com Bergson para tratar do tempo como elemento genético de produção de imagens. Na década de 70 Deleuze mostrou-se um apreciador e frequentador de espaços dedicados à exibição de filmes, tendo tornado público seu primeiro diálogo com o cinema em 1974 em defesa do filme LesAutres, dirigido pelo argentino Hugo Santiago Muchnick. Ainda em 74 é lançado o filme George qui? Com a participação de Deleuze interpretando o filósofo Robert de Lamennais, amigo e conselheiro da escritora George Sand. Em 1976 Deleuze

\footnotetext{
${ }^{3}$ Raymond Bellour em comunicação de 1995, Pensar, contar: o cinema de Gilles Deleuze, na abertura do colóquio filmológico internacional "Gilles Deleuze: O cinema", incluída na coletânea de textos organizada por André Parente: Cinema/Deleuze, mostra que Deleuze não havia dedicado um livro inteiro a uma arte até as publicações dos seus livros sobre cinema; havia sim escrito sobre um pintor, sobre obras literárias específicas, mas não sobre "uma arte, um domínio" (2013, p. 233). Em Bellour notamos um importante adendo sobre a manifesta intenção de Deleuze por não escrever uma história do cinema e sim uma taxionomia das imagens, pois para aquele os dois volumes sobre cinema demonstram uma ordenação conceitual. Nesse sentido, Deleuze não teria realizado uma história cronológica do cinema, mas uma "história-artista do cinema. A primeira história conceitual do cinema" (p. 236). Estariam, portanto, cinema e filosofia reunidos "na medida em que o filósofo e o cineasta são tributários, um da não história que se atribui, o outro da multiplicidade de histórias que se dá" (ibid.).
} 
publica nos Cahiers du Cinéma a entrevista Trois questionssur Six fois deux sobre a série de televisão dirigida por Godard. Em 1977, outro texto de Deleuze é publicado, dessa vez no Le Monde em defesa do filme acusado de antissemitismo L'Ombre des Anges, dirigido pelo suíço Daniel Schimid. Já na década de 80 Deleuze se fez freqüentador do Studio 43 que funcionara como espaço dedicado ao cinema sendo uma sala de exibição Artet Essai, que atualmente compreendemos por cinema independente, tendo sido posteriormente um espaço de exibição de filmes de vanguarda.Em 1986 Deleuze escreve o prefácio Lettres à Serge Daney: optimisme, pessimisme et voyage para o livro de Serge DaneyCinéJournalque reunia textos do autor escrito de 1981 a 1986 para a revista de cinema Libération.

Nesse itinerário de cinéfilo, seja como espectador, como ator amador e também como pensador de cinema, encontramos nos anos 80 a imersão do filósofo no diálogo entre filosofia e cinema, pois de 1981 a 1985 foram dedicados ao cinema três anos letivos distribuídos em 4 cursos $^{4}$ :(i) imagem-movimento, (ii) uma classificação dos signos e do tempo, (iii) verdade e tempo: a potência do falso, e,(iv) pensamento; bem como em 1983 a publicação do livro Cinéma 1: L'imagemouvement,e em 1985 o Cinéma 2:L'image-temps. Ainda nesse período,de 1982 a 1988, Deleuze orientou a tese de doutorado do pesquisador brasileiro André Parente em estudos na Universidade Paris VIII sob o título Narratividade e não narratividades filmicas, tendo sido esta sua primeira orienta-

\footnotetext{
${ }^{4}$ Publicação dos cursos nos formatos de áudio e textos transcritos no site da Universidade Paris 8: $\langle$ http://www2.univ-paris8.fr/deleuze/rubrique.php3?id_rubrique=19>.
} 
ção acadêmica a tratar de cinema.

Esse breve resgate biográfico da relação de Deleuze com o cinema se faz importante para compreender a escolha pela arte cinematográfica como objeto de estudonum processo de composição produtiva com o construto teórico bergsoniano, especialmente por evidenciar no início do livro Imagem-movimento que pretende menos se valer do cinema para ilustrar seu texto e mais fazer do seu texto uma ilustração de grandes filmes. Essa provocativa deleuziana, somada ao histórico de cinefilia, nos faz compreender que estaria o filósofo uma vez maisse valendo de uma aliança com outro modo de criação artísticapara operar seu modo próprio de criação de conceitos filosóficos. Nesse sentido, seguindo os capítulos de Imagem-movimento e Imagem-tempo, percebemos o uso de termos como corte imóvel, corte móvel, montagem, plano, enquadramento, narrativa clássica, duração, dentre outros que funcionam tanto para a filosofia quanto para $\mathrm{O}$ cinema, sendo que ora são remetidos ao movimento fílmico ora ao movimento qualitativo bergsoniano. Em se tratando da profundidade de campo enquanto técnica conhecida na história da pintura, na fotografia e no cinema, Deleuze a coloca em funcionamento na filosofia ao desenvolver os lençóis de passado e as pontas de presente de uma metafísica da memória.

Os livros sobre cinema provocam o questionamento pelo percurso filosófico do autor, sobretudo ao trazer como partes dos títulos dois conceitos demasiados caros à história da filosofia: movimento e tempo. Nesse sentido, imersos nos capítulos de Cinema 1e 2, encontramos em Bergson um aliado de Deleuze para lidar com uma questão latente: Que 
quer dizer percepção?

Pierre Montebello no livro Deleuze: filosofia e cinemaevidencia as interferências construídas por Deleuze entre pensamento, tempo e movimento diante do que nomeia de "práticas de imagens no cinema" e de "práticas conceituais na filosofia". Segundo aquele, ao recorrer a Bergson, estaria Deleuze recorrendo ao primeiro filósofo que observou e falou do cinema como reflexão sobre o movimento (2016, p. 14) e embora tenha Bergson expressamente criticado o método cinematográfico como reprodução do movimento a partir da quantificação espacial, foi justamente este quem apresentou instrumentos filosóficos para a superação do dualismo entre mundo e consciência. Montebello refaz o percurso da questão sobre a percepção e identifica a origem desse dualismo quando da modernidade galileo-cartesiano e sua metafísica da natureza que compreende a matéria e o movimento mecânico como indispensáveis ao mundo, entretanto essa concepção moderna que rompe com a concepção aristotélica de movimento qualititativo é a mesma que explora regiões não pertencentes ao próprio movimento mecânico, quais sejam: cogito, alma, eu puro, domínio transcendental, consciência. Estava posta, portanto, a base do dualismo entre leis de corpos e faculdades da consciência, entre mecanismo e alma, entremovimento e ideia.

Diante da crise do dualismo colocada a partir(i) do surgimento de novas reflexões que compreendem que o mundo não pode ser separado da consciência e (ii) do nascimento do cinema no fim do século XIX,Bergson é o filósofo que em resposta à crise, compreenderá a consciência como sendo já alguma coisa e nãoconsciência de alguma coisa. Em A Evolução Criadora de 1907, o filósofo trata es- 
pecificamente do que chamou de ilusão cinematográfica referindo-se à percepção natural. Pois bem, é nesse momento do capítulo IV: O mecanismo cinematográfico do pensamento e a ilusão mecanística que Bergson estabelece a aliança entre a tradição filosófica e o cinema, pois teria sido o pensamento filosófico uma espécie de cinema interior, e o cinema, por sua vez, uma derivação moderna e tecnológica do método historicamente utilizado na filosofia. O que permite a Bergson estabelecer a aliança é o conceito de percepção natural que seleciona imagens no mundo, fixando-as e em seguida justapondo-as produzindo um tipo de movimento ilusório, pois em fato o que ocorre é a quantificação de imagens fixas dispondouma após a outra. A denúncia de Bergson denuncia que o cinema nasce revelando o modo como o movimento foi compreendido pelo pensamento filosófico até então, exclusivamente como percepção naturalque fixao movimento para reproduzí-lo.

Diante da questão Que quer dizer percepção?, Montebello apresenta a análise que possibilita compreender como pôde Deleuze valer-se da crítica d'A Evolução Criadora justamente para tratar o cinema como prática artística que rompe com a percepção natural. Três são as respostas identificadas por Montebello e que abordama especificidade do cinema e o problema da percepção: (i) Bergson e a fenomenologia cujo cinema reproduz as condições da percepção natural; (ii) linguísticos e semiólogos influenciados por Christian Metz cujo cinema é uma linguagem, e, Eisenstein e Vertov que vêem no cinema uma língua; (iii) Deleuze para quem a percepção natural só pode ser compreendida se for antecedida por uma percepção objetiva, ou seja, por uma percepção de 
movimento.

Bergsonserá a fonte para Deleuze anunciar a boa nova do cinema como resolução da crise do dualismoe a posição fundamental para tratar da nova percepção é extraídado primeiro capítulode Matéria e Memória, que trata da consciência numa relação com o universo sendo ela mesma já alguma coisa e não decalcagem de alguma coisa. Para Bergson em 1896, ano de publicação do Matéria e Memória, texto contemporâneo à primeira exibição cinematográfica ocorrida em 1895, as imagens agem e reagem exprimindo modificações do universo, e é na relação das imagens que hápercepção, de modo que ter consciência do mundo é da ordem do movimento dado diretamente no mundo.

O que diz Bergson sobre a percepção: "Chamo de matéria o conjunto das imagens, e de percepção da matéria essas mesmas imagens relacionadas à ação possível de uma certa imagem determinada, meu corpo" (BERGSON, 2010, p. 17). Ora, a arquitetônica da percepção bergsoniana se dá do seguinte modo: o universo é um conjunto material onde as partes de cada objeto se dão às partes de outro objeto segundo leis naturais, de modo que agindo e reagindo uns sobre os outros temos um conjunto de imagens. A passagem do objeto à imagem implica falar de um objeto que se relaciona com outro objeto, ambos dados na materialidade dos próprios objetos, e no processo dessa relação material, temos imagens.Dentre as imagens há uma que prevalece e essa é o nosso corpo. $\mathrm{O}$ corpo, entretanto difere das outras imagens não porque tenha outra natureza em relação às demais imagens, pois todas as imagens, incluindo o corpo, se dão no conjunto do mundo material, sendo que a diferença do corpo é que este seleciona a maneira de devolver o 
que recebe, em outros termos, o corpo é uma imagem que opera por seleção quando do processo de ação e reação. Nesse sentido o corpo é uma imagem que sobressai às demais imagens justamente por selecionaro que vai ou não ser respondido, possibilitando um intervalo entre a ação recebida e a reação emitida, sendo que os objetos que cercam meu corpo refletem a ação possível do meu próprio corpo sobre eles. Vemos, pois, a percepção diretamente vinculada à imagem e que por sua vez vincula-se a um tipo de movimento molecular, diria indispensável, entre objetos dados na matéria.Pode-se ainda compreender dois tipos de imagens em Bergson: um primeiro regime de imagens entre os diversos objetos do universo e que trata das imagens que são dadas mas não as percebemos, e um segundo regime de imagens que é a percepção e que se caracteriza por ser um recorte do universo a partir do que interessa à imagem que sobressai, o corpo. Por exemplo no caso de um deserto nós não percebemos a totalidade dos grãos de areia individualizados, mas percebemos sim um recorte que nos interessa, a parte do chão de areia que piso e que por tal chamo de deserto. No caso da abelha ela não percebe todo o movimento da botânica, mas percebe as plantas que lhe interessam para coleta do pólen. Cada ser vivo opera recortando o mundo material do primeiro sistema de imagem conforme seus interesses. Portanto, o universo possui imagens independentes do corpo, sendo que algumas dessas imagens serão recortadas quando de interesse do corpo e portanto percebidas.

Pois bem, Deleuze ao identificar o movimento do mundo como condição de percepção, compreenderá que falar de imagem é necessariamente falar de movimento da 
matéria, concepção esta descrita acima e que apresenta as imagens como uma evocação das partes elementares da matéria em interação, numa espécie de atomismo e mecanismo ${ }^{5}$, que nesse sentido se (i) consciência é já alguma coisa e não representação de alguma coisa, que (ii) imagens agem e reagem no mundo, e (iii) que o corpo é uma imagem que se destaca em relação às outras imagens,tem-se portanto a compreensão de que perceber é ter imagem do próprio movimento da matéria na fluidez do mundo.Assim, para Montebello, encontramos aí a elaboração primeira de imagemmovimentodeleuzeana da arte cinematográfica (2016, p.21) como sendo um corte móvel da duração, ou seja, percepção do movimento de ação e reação entre imagens no mundo.

Qual a operação realizada por Deleuze? Ele tira a percepção do império do natural e insere a percepção objetiva como pertencente ao próprio movimento do mundo. Deleuze coloca a percepção diretamente nas coisas, de modo que se na percepção natural as coisas do mundo são pensadas pela subjetividade, agora são as coisas que trazem em si a percepção, ou seja, as coisas são desde já percepção em si mesmas, as coisas são imagens. $\mathrm{O}$ olho que percebe não está fora das coisas, o olho é já parte das coisas nelas mesmas. Daí a fonte bergsoniana de que consciência não é consciência de alguma coisa, mas consciência é alguma coisa. A per-

\footnotetext{
${ }^{5}$ Deleuze emCinema 1 ao tratar das escolas de montagem, destaca Vertov como cineasta de um metacinema cujo programa encontra no materialismo bergsoniano ressonância na filosofia: "O que Vertov materialista realiza através do cinema é o programa materialista do primeiro capítulo de Matéria e Memória: o em-sida imagem. O cine-olho, o olho não-humano de Vertov, não é o olho de uma mosca ou de uma águia, o olho de um outro animal(...) É, ao contrário, o olho da matéria, o olho na matéria, que não se submete ao tempo, que "venceu" o tempo, que acede ao "negativo do tempo", e não conhece outro todo senão o universo material e sua extensão". (DELEUZE, 2015, p. 118).
} 
cepção objetiva nos coloca diretamente no movimento das coisas, de modo que ela se dá sob duas faces do movimento: como movimento temporal e como movimento espacial.Aqui é indispensável compreender que Deleuze ao falar de percepção objetiva, diz-nos de percepção de movimento, o que justamente marca a distinção entre percepção objetiva e percepção natural. Na percepção objetiva o movimento é condição da imagem, é o que Deleuze chama de em-si da imagem, ou seja, o movimento que liga as imagens na relação de ação e reação. Esse movimento é espacial enquanto percepção de fato e é temporal enquanto percepção de direito. A percepção de fato nos dá o movimento da matéria, um fluir-matéria cujas imagens evocam as partes elementares da matéria em interação, temos assim os limites perceptíveis e visíveis do movimento, é a essa percepção que Deleuze chama de translação. A percepção de direito nos dá o movimento temporal, como alguma coisa que passa mas não vemos passar e que atravessa a percepção material, temos assim o limite imperceptível do movimento, é a essa percepção que Deleuze chama de mudança.A imagemmovimento indica sempre uma interação entre as partes das coisas e uma mudança no todo, interação entre translação e mudança.

E qual é o lugar do cinema diante da percepção objetiva deleuzeana? A imagem cinematográfica se insere no movimento das cosias e extrai a mobilidade dessas coisas, a mobilidade espacial e temporal. Ou seja, a boa nova do cinema como arte moderna é estabelecer a relação entre consciência e universo, entre imagem e movimento postas na tela de exibição. A demarcação de Deleuze em relação a Bergson é tratar o cinema não como projeção de imagens fixadas 
quantitativamente, é antes, encontrar no cinema uma arte criadora que projeta imagens cujo movimento não é ela quem faz e nem é ela quem cria, mas é ela sim quem nos insere diretamente no movimento da percepção objetiva, como sendo fotografias tiradas no interior das coisas e não meramente fotografias tiradas das coisas. Teria Deleuze feito da consciência de Bergson que diz da experiência de duração uma consciência no cinema que dada em planos, divide os objetos em conjuntos respectivos e os coloca numa mesma duração.

De posse da percepção de movimento deleuzeana como passo importante para acompreensão da leitura filosófica do cinema, o percurso do texto constitui-se nos próximos momentos: apresentação das 3 teses de Deleuze sobre as críticas de Bergson ao cinema; em seguida uma descrição pontual sobre um maquinismo da imagem ou o modo como Deleuze aborda a produção das imagens no cinema, e o terceiro momento trata da inserçãoda profundidade de campo como técnica fílmica relacionada às teses bergsonianas.

\section{Primeiro COMEntário a Bergson: As três teses de DELEUZE SOBRE BERGSON ORIENTADAS PARA O CINEMA}

No livro Cinema 1: Imagem-Movimento são três as teses de Bergson apresentadas por Deleuze sobre o movimento:

Tese i) $O$ movimento não se confunde com o espaço percorrido. Assim, tem-se uma apresentação do corte móvel a partir de imagem-média.

Tese ii) $\mathrm{O}$ erro consiste sempre em reconstituir o mo- 
vimento através de instantes ou posições e háduas maneiras de fazê-lo: antiga e moderna. Assim, tem-se uma apresentação da noção de equidistância a partir do instante qualquer.

Tese iii) Não só o instante é um corte imóvel do movimento, mas o movimento é um corte móvel da duração. Tem-se assim, uma apresentação do movimento com duas faces: uma no espaço com os cortes imóveis, a translação, e outra no tempo com o corte móvel, a duração.

A primeira tese é desenvolvida num processo de desmistificação da tentativa de reconstituir o movimento a partir de um espaço percorrido que é divisível e homogêneo, pois trata do que passou. Nos termos familiares ao cinema, o espaço percorrido é possível a partir de cortes instantâneos, cortes estáticos retirados de um fluxo corrente, sendo que esse corte é possível ao fixar um ponto dentro do fluxo. De outro modo, o movimento bergsonianoé o ato de percorrer, remete ao presente e por tal é heterogêneo pois não se reduz a uma fixidez,é ainda irredutivel porque se faz sempre no intervalo entre dois instantes ou duas posições.

A crítica à reconstituição do movimento a partir do espaço percorrido se fundamenta na impossibilidade de associar: posições no espaçoque são cortes imóveis + instantes no tempo que é tempo abstrato por tratar de uma fórmula arbitrária que compreende o movimento como sendo externo às coisas. Em oposição a essa fórmula, Deleuze apresenta outra fórmula: movimento real $\rightarrow$ duração concreta a partir do corte móvel, sendo que movimento, portanto, não é o deslocamento de corpos de um ponto a outro, mas movimento é compreendido como mudança de natureza. Diz Deleuze:

Se eu considero as partes ou os lugares A e B abstratamente, eu não 
compreendo o movimento que vai de um ao outro. Mas eu estou em A, com fome, e em B há alimentos. Quando atingir B e comer, o que terá mudado, não é somente meu estado, é o estado do todo que compreende $\mathrm{B}, \mathrm{A}$ e tudo aquilo que havia entre os dois (DELEUZE, 1985, p. 17).

Partindo da crítica de Bergson ao aparelho cinematógrafo como reprodutor do movimento como sucessões de cortes instantâneos num tempo abstrato, Deleuze relê a crítica demonstrando que o cinema opera, não exclusivamente na projeção de instantâneos, mas por instantâneos que são os cortes imóveis numa mecânica de 24 fotogramas por segundo, de modo que na tela não visualizamos cada foto separada do conjunto das 24 por segundo, visualizamos sim uma imagem-média resultante da soma dos 24 fotogramas rodados em 1 segundo. Vemos, portanto, que o corte móvel é inserido a partir da imagem-média; nos termos do próprio Deleuze: "o movimento pertence à imagem-média enquanto dado imediato"(1985, p. 11).

$\mathrm{Na}$ segunda tese, Deleuze compreende que antigos e modernos incorreram no erro de reconstituir o movimento através de cortes imóveis, de instantes ou posições. Os antigos remeteram o movimento a elementos inteligíveis, formas ou ideias transcendentais, sendo que a passagem de uma forma a outra é regulada por uma seleção de instantes privilegiados ${ }^{6}$, ou como poses essenciais que revelam a mais

\footnotetext{
${ }^{6}$ Jacques Aumont, professor na Paris III, no recém fundado departamento de cinema em 1969, em livro publicado na década de 90 , aborda a relação entre instante pregnante e instante qualquer. Numa perspectiva diferente do apontamento que Deleuze faz entre instante privilegiado (que remete a poses) e instante qualquer (que remete a instantâneos/fotogramas), em Aumont há a compreensão de que o instante qualquer não resolveu por completo o problema da representação do melhor momento quando do real. Segundo o autor haveria uma família de fotógrafos que se dedicaram ao instante expressivo, que retém um instante autêntico (cita Cartier-Bresson, Doisneau, Robert Frank e Kertesz). A representação pictórica no século XVIII diante do problema entre reCont.
} 
nobre dentre outras poses. Os modernos, por sua vez, romperam com as poses em prol dos cortes, sendo que estes cortes são possibilitados através de marcações entre instantes quaisquer.Ao reconstituir o movimento nessa perspectiva, a concepção modernaprocede determinando pontos fixos com distância igual entre os pontos, de modo que o movimento é justamente a reconstituição do espaço percorrido. Ora, é dessa concepção moderna que se origina o cinema.

Deleuze parte da noção de eqüidistância como sendo a igual distância entre algos, ou, algo localizado entre distâncias iguais. Veja-se: foto $1 \ldots$ foto $2 \ldots$ foto 3 foto 4 etc. $\mathrm{O}$ sinal "... " representa a equidistância, observando-se que esta encontra-se em qualquer distância igualitária entre cortes relacionados, logo, mostra-se como invariável independente, daía denominação como instantes quaisquer. Tal como na concepção moderna, o cinema se utiliza de instantes quaisquer, o que difere da concepção antiga com seus instantes privilegiados para reconstituir o movimento ${ }^{7}$.

presentar todo o acontecimento ou apenas um instante, considerou como resolução o instante pregnante ou instante mais favorável como sendo o instante que exprime a essência do acontecimento (p. 241). Assim, o instante pregnante revela um estatuto estético, posto que a cena representada não correspondesse a uma realidade fisiológica, mas tratava sim de uma cena produzida em referência a um sentido retórico (p. 242-243). Por volta de 1860, a fixação de um instante real reaparece, sobretudo com o instante fotográfico enquanto uma representação autêntica de um instante extraído de um acontecimento real. Dessa possibilidade de retenção de um instante qualquer que se percebeu que os supostos instantes figurados pela pintura tinham sido inteiramente reconstruídos (p. 243). [AUMONT, Jacques. A imagem. Trad. Estela dos Santos Abreu, Cláudio C. Santoro; Revisão técnica Rolf de Luna Fonseca - 16ª ed. - Campinas, SP: Papirus, 2012].

${ }^{7}$ A compreensão de Deleuze do instante qualquer no cinema semelhante ao instante qualquer do pensamento moderno em substituição ao instante privilegiado dos antigos, remete-nos à leitura de Pamart que evidencia a influência de Kant nos livros de cinema de Deleuze justamente como o aliado que rompe com o "velho corte disjuntivo" da filosofia antiga entre essência e aparência em prol do "corte conjuntivo" kantiano que traz o pensamento para o campo da experiência ao apresentar as condições de aparição do fenômeno, pois é no fenômeno que está o conhecimento e Cont. 
Vimos que na primeira tese Deleuze subtrai a noção de corte móvel a partir da imagem-média. $\mathrm{Na}$ segunda tese, subtrai a noção de instantes quaisquer a partir da equidistância. Pois bem, na terceira tese, Deleuze avança para fechar sua releitura de Bergson partindo justamente da crítica que o último fez ao aparelho cinematógrafo.

Diz a terceira tese que o instante não é apenas um corte imóvel do movimento, mas o movimento é um corte móvel da duração, sendo que essa seria, portanto, a fórmula bruta do cinema. O percurso que Deleuze nos revela é de que o cinema opera com um movimento duplo: por cortes imóveis e por cortes móveis, e que ambos remetem a tendências distintas: (i) enquanto movimento de translação no espaço, e, (ii) enquanto movimento que exprime uma mudança na duração. A partir dessa dupla face do movimento, são estabelecidos três níveis na terceira tese: i) os conjuntos ou sistemas fechados: que se definem através dos objetos discerníveis ou das partes distintas: os cortes imóveis; ii) movimento de translação: que se estabelece entre esses objetos e modifica suas posições respectivas; iii) a duração ou o todo: realidade imaterial que não para de mudar segundo suas próprias relações.

Percebemos que ao introduzir essa terceira tese em Imagem-movimento, Deleuze estabelece uma relação com o livro de 1966, Bergsonismo. Em1966 Deleuze não trata de cinema, entretanto, é nesse texto que encontramos os conceitos de duração e atual,importantes para a compreensão das incur-

não nas essências. [PAMART, Jean-Michel. Deleuze etlecinéma: l'armaturephilosophiquedes livres surlecinéma. - Paris: ÉditionsKimé, 2012. p. 58]. 
sões conceituais dos livros sobre cinema na década de 80 . Leia-se:

O passado e o presente não designam dois momentos sucessivos, mas dois elementos que coexistem: um, que é o presente e que não para de passar; o outro, que é o passado e que não para de ser, mas pelo qual todos os presentes passam. É nesse sentido que há um passado puro, uma espécie de passado em geral: o passado não segue o presente, mas ao contrário, é suposto por este como a condição pura sem a qual este não passaria (DELEUZE, 2008a, p. 45-46).

Pois bem, o passado em geral é a duração. Compreendendo que todo o nosso passado coexiste com o presente, hánesse sentido concentrações distintas do passado em geral (ou passado puro, ou passado ontológico) contraídas no presente, sendo que essas contrações se atualizam no presente. Tomemos um passado de direito que inclui todos os passados e todos os presentes desses passados, estando todos em conexão. O presente é o real concreto com as atualizações do passado. Diz Deleuze: "Tudo se passa como se o universo fosse uma formidável memória" (2008a, p. 61). Ora, a arte é um meio de atualização dessa memória pura, dessa grande memória que remete ao passado em geral, daí a pertinência do cinema com seu duplo movimento em cortes imóveis na relação entre os conjuntos e objetos, cujo maquinismo é a translação no espaço como movimento de atualização, e, em corte móvel cujo maquinismo é uma abertura do todo que muda de natureza a cada nova relação entre os cortes imóveis como movimento de duração.

A terceira tese faz referência ao movimento de translação e à duração que encontramos no Bergsonismo: "há contração, porque a lembrança, tornando-se imagem entra em coalescência com o presente, ainda,"contração psicológica, 
translativa, pela qual cada lembrança, em seu nível, deve passar para atualizar-se e tornar-se imagem” (2008a, p. 51). Essa conexão nos permite compreender que o conceito de imagem é trabalhado no cinema a partir da criação artística e nesse sentido as imagens da taxonomia que o autor se propõe a realizar, são, em evidência, atualizações do passado ontológico.

Assim, a terceira tese é a incursão para evidenciar que o cinema, tal como a filosofia bergsoniana, estão tratando do problema do movimento ${ }^{8}$, posto que o movimento se dá de dois modos: no processo de atualização, daí a translação, e ainda, no movimento do Todo, daí a duração. Enquanto translação temos o corte imóvel, ou seja, as partes individuadas e atualizadas no presente. Enquanto movimento do Todo, temos o corte móvel, que a partir da atualização das partes sofre transformação qualitativa dada a conexão com as partes. Nessa perspectiva que o cinema sendo composto de cortes imóveis e cortes móveis distancia-se da tentativa de reconstituir o movimento a partir do percurso percorrido, sobretudo porque o movimento expressa mudança de qualidade.Nos termos deleuzeanos de Imagem-movimento em referência a Bergson:

ao colocar açúcar num copo com água devo esperar que o açúcar se

\footnotetext{
${ }^{8}$ Deleuze diz em entrevista a Gilbert Cabasso e FabriceRevault d'Allonnes em 18/12/1985, na revista Cinéma, no 334: "É verdade que os filósofos se ocuparam pouco do cinema, mesmo quando o frequentavam. E no entanto, há uma coincidência. É ao mesmo tempo que o cinema surge e que a filosofia se esforça em pensar o movimento. Mas talvez seja esta a razão pela qual a filosofia não atribui suficiente importância ao cinema; ela está demasiado ocupada em realizar por si só uma tarefa análoga à do cinema; ela quer pôr o movimento no pensamento, como o cinema o põe na imagem. Há uma independência das duas pesquisas, antes que haja encontro possível" (DELEUZE, 2008b, p. 75).
} 
dissolva [...] o próprio movimento de translação que desprende as partículas de açúcar e as coloca em suspensão na água exprime uma mudança no todo, isto é, no conteúdo do copo, uma passagem qualitativa da água onde há açúcar ao estado de água açucarada. Se eu agito com a colher, acelero o movimento, mas modifico também o todo que compreende agora a colher, e o movimento acelerado continua a exprimir a mudança no todo. [...] O copo de água é exatamente um conjunto fechado que compreende partes, a água, o açúcar, talvez a colher; mas isso não é o todo. $O$ todo se cria e não para de se criar numa outra dimensão em partes, como aquilo que leva o conjunto de um estado qualitativo a outro, como puro devir incessante que passa por esses estados. É nesse sentido que ele é espiritual ou mental [...] se os conjuntos estão no espaço, o todo, os todos estão precisamente na duração, são a própria duração na medida que ela não para de mudar (DELEUZE, 1985, p. 18-20).

A necessidade por compreender as 3 teses é instrumental para acompanhar o passo que Deleuze opera rumo à sua taxinomia das imagens cinematográficas, pois, ao encontrar a imagem-média na $1^{\text {a }}$ tese, bem como a equidistância na imanência dos instantes quaisquer na $2^{a}$ tese, e ainda, na $3^{a}$ tese a dupla face do movimento como corte imóvel e como corte móvel, vislumbramos um indicativo de que Deleuze apresenta uma rearticulação entre espaço e tempo, sobretudo ao inserir o movimento como mudança de qualidade enquanto categoria problemática no pensamento na sua empreitada, quiçá, por uma nova imagem do pensamento 9 .

\footnotetext{
${ }^{9}$ Encontramos o problema da imagem do pensamento em três momentos nos escritos de Deleuze: Nietzsche e a Filosofia (1962) cujo título Nova imagem do pensamento; e ainda, A imagem do pensamento em Proust e os Signos (1964), e, Diferença e Repetição (1968), capítulos que revelam, destacadamente um empreendimento político do pensamento de Deleuze no embate com o pensamento fundado na representação.
} 


\section{Quarto COMEntário a Bergson: $A$ MEMórla $E$ A COEXISTÊNCIA NA IMAGEM}

O quarto comentário a Bergson em Imagem-Tempo traz uma relação de proximidade com a terceira tese do primeiro comentário em Imagem-Movimento, pois trata em especial da imagem fundada no passado e a inserção do movimento não submetido ao tempoparalisadono pensamento filosófico, bem como o movimento não submetido ao tempoparalisado enquanto produção cinematográfica.

Deleuze faz uma distinção entre cinema clássico e cinema moderno, cujo caráter diferenciador se dá sobremaneira a partir da montagem. No cinema clássico a montagem é trata por Deleuze sob4 formas: americana como sendo orgânica-ativa, soviética como dialética orgânica ou material, francesa como quantitativo-psíquica, e, o expressionismo alemão como intensivo-espiritual. Numa dessas formas que é a montagem americana, a organicidade é expressa na grande forma sensório-motora S-A-S em que há uma situação (S) que desencadeia umaação (A)e que por sua vez reconfigura a situação inicial (S). Enquanto técnica fílmica, essa forma é conhecida como narrativa clássica,onde há a identificação de uma situação problema inicial, cujapersonagem age para resolver o problema reestabelecendo uma nova situação com o problema inicial resolvido. Nesse sentido, a montagem é realizada na sucessão de planos continuados, numa relação de ação e reação. Por exemplo: uma personagemestá em casa preparando o almoço, assim temos um plano explicativo que apresenta a personagem na cozinha preparando os alimentos com a panela no fogão. Paralelamente, corta-se esse plano da cozinha 
para um plano seguinte onde uma outra personagem é filmada chegando nas proximidades da casa onde no plano anterior a personagem cozinhava. Esse plano seqüente mostra a personagem com um revólver na mão caminhando em direção à cozinha. $O$ terceiro plano revela a continuidade da narrativa, de modo que o problema foi apresentado e a ação comosendo um possível assassinato, cujo plano final será a reconfiguração da situação inicial: ou há o assassinato ou não há. Essa organicidade do cinema clássicoé operada para extrair uma imagem indireta do tempo, pois há um discurso de verdade que referencia o movimento, trata justamente de uma reconstituição externa do movimento, cujas técnicas do cinema, incluindo a imagem-média e a eqüidistância estão empregadas numa composição das imagens para dar acesso a uma totalidade. A composição de imagens-movimento no cinema clássico se dá na relação dupla de movimento entre as partes e o conjunto, e, de movimento para o todo e suas mudanças. Nesse sentido, planos contínuos são utilizados de modo explicativo que encadeiam uma continuidade de momentos para revelar uma mudança no todo, em outros termos, a sucessão dos planos é operada para apreender indiretamente, através de relações das imagens-movimento, algo que muda do início ao fim do filme.

Pois bem, no cinema clássico tem-se a imagemmovimento que nos dá uma imagem indireta do tempo. No cinema moderno, por sua vez, tem-se a imagem-tempo que nos dá uma imagem direta do tempo. Se na narrativa clássica os planos eram montados de modo a constituir externamente uma continuidade temporal, agora, no cinema moderno, a montagem é marcada por técnicas fílmicas que 
não se fazem tão e somente por paradas do movimento, um plano após o outro seguido de outro plano cujo objetivo é orientar uma explicação de mudança no todo, diversamente, o cinema moderno se vale de falsos-raccords, de travellings, de planos sequências dentro de um único plano a partir da profundidade de campo que extraem a coexistência dos tempos na imagem.

Se tomarmos a imagem-movimento por analogia à matéria e a imagem-tempo por analogia à memória, "aproximamo-nos, aqui, de um dos aspectos mais profundos e, até mesmo, dos menos compreendidos do bergsonismo: a teoria da memória" (DELEUZE, 2008a, p. 42), vislumbrando que o cinema moderno trata justamente dessa teoria da memória. Tal teoria compreende o passado como ser em si que jamais deixa de ser cuja forma é a sua conservação, e o presente como a forma com a qual o ser não é ao se consumir. Nesse sentido o passado deixa de agir e de ser útil, mas não deixa de ser, de outro modo, o presente é útil e age, entretanto deixa de ser. Se o presente se distingue do passado é porque é a presença de alguma coisa, que justamente deixa de ser presente ao ser substituída por outra coisa, ou, "como adviria um novo presente, se o antigo presente não passasse ao mesmo tempo em que é presente?" (DELEUZE, 2007, p. 45). Ora, nesse sentido, o que passa é o presente e o que permanece é o passado, portanto, encontramos um passado ontológico, "um passado em geral, que não é o passado particular de tal ou qual presente, mas que é como que um elemento ontológico, um passado eterno e desde sempre, condição para a passagem de todo presente particular" (DELEUZE, 2008a, p. 43).

Perguntamos nesse sentido qual a relação entre o pas- 
sado ontológico bergsoniano e o cinema moderno? Ao romper com um movimento uniforme e contínuo, o cinema de $\mathrm{Ozu}$, do neorrealismo italiano, de Godard, Resnais, Welles e outros, produz uma imagem que extrai o virtual como elemento na própria imagem, ou seja, a imagem no cinema moderno possibilita uma apresentação do passado ontológico.

Para Deleuze no início do quarto comentário a Bergson, o maquinismo de uma metafísica da memória se dá do seguinte modo:Precisamos nos (i) instalar no passado em geral, depois (ii) escolhemos entre as regiões e lençóis e em qual deles acreditamos estar escondida a lembrança e (iii) retornar ao presente para atualizar uma imagem-lembrança.

O cinema clássico opera com um tipo de imagem sensório-motora que é constituídapor semelhanças que retém das coisas apenas o que lhe interessa, como que acumulando objetos por abstração num movimento horizontal de continuidadeque descreve a relação entre ação e reação. $\mathrm{O}$ cinema moderno, por sua vez, opera a partir do que Deleuze chama de um menor circuito entre imagens, uma coalescência entre imagem atual e imagem virtual. Esse menor circuito é o limite interno das relações entre imagens, como sendo o ponto elementar na composição das imagens, é o ponto de indiscernibilidade onde há a imagem bifacial produzida justamente num reflexo, numa duplicidade da imagem atual em imagem especular. Essa imagem bifacial é, portanto, "a razão ou antes o núcleo da imagem ótica e sonora pura e de suas composições" (DELEUZE, 2007, p. 88), imagem esta queDeleuze chamou de imagem-cristal.

Amplificando esse circuito da imagem no cinema moderno, temos nesse sentido, duas imagens: (i) a imagem óti- 
ca e sonora pura cuja percepção não se prolonga em ação, pois a situação em que a personagem se encontra enfraquece a mecânica entre ação e reação, como que "curtacircuitando" as capacidades motoras de resposta; e, (ii) imagemlembrança que é suscitada pela própria imagem ótica e sonora pura. A imagem-lembrança é uma imagem mentalconectada à imagem ótica pura, sendo a primeira como que a concepção de "outras respostas possíveis ${ }^{10}$, mais ou menos vizinhas, mais ou menos distintas: algo real e imaginário, físico e mental, descrição e narração, atual e virtual”. Ambas, imagem ótica pura e imagem-lembrança refletem-se ao ponto de se confundirem caindo num ponto de indiscernibili-

\footnotetext{
${ }^{10} \mathrm{O}$ termo possivel utilizado por Deleuze remete não à variação de cópias diante de um modelo referente, mas sim ao mecanicismo da percepção objetiva tratada no início desse texto e que compreende o corpo como uma imagem que seleciona das outras imagens o que lhe é conveniente. Possivel, portanto, não como uma simulação dentre várias possibilidades, por exemplo: "A filosofia é a mãe do pensamento" como sendo o modelo verdadeiro para acesso à sabedoria, desse modelo teríamos os possíveis desdobramentos, as variações decalcadas, (a) A filosofia é filha da matemática, então esta é a mãe, portanto portadora do pensamento verdadeiro"; ou, (ii) A arte é a mãe da filosofia e da matemática, portanto, o pensamento verdadeiro é criação artística"; ou (iii) A ciência criou filosofia e arte, logo, o mais nobre e fundante pensamento é científico. Percebe-se que a concepção de possivel como variação de um modelo trata de uma composição excludente entre as variações que se legitimam conforme a variação mais próxima do modelo referente. De outro modo, quando Deleuze utiliza o termo possível para tratar da imagem-lembrança, em fato trata de evocar a indiscernibilidade quando da relação da imagem corpo com outras imagens, pois é nessa relação que se dá a percepção objetiva enquanto recorte seletivo. A relação ocorre na mecânica ação-reação, sendo que o corpo difere das outras imagens justamente porque este possui um intervalo no interior da mecânica, ou seja, entre ação e reação há uma zona de indiscernibilidade, e é nessa zona que transpassa o que Deleuze chama de possivel como imagem-lembrança. Portanto, entre $\mathrm{o}$ ato de receber e $\mathrm{o}$ ato de responder, há uma imanência de probabilidades que se dão no fluxo do próprio mundo, de modo que a resposta possivel está conectada com o movimento qualitativo das imagens que é a mudança, movimento este inclusivo. Nesse sentido compreendemos nessa passagem o termo possivel como resposta que traz o todo, produzida a partir do conjunto de probabilidades refletidas nesse todo e que são inclusivas justamente por se tratarem de respostas distintas que não se anulam mas que pertencem ao fluxo ininterrupto do universo. Por exemplo: (a) a filosofia pensaproduzindo conceitos" como sendo uma resposta distinta dada numa zona deindiscerbilidade e a essa resposta se conecta também outra possível resposta, (b) a arte pensa produzindo blocos de sensações; e soma-se ainda que (c) a ciência pensa produzindo funções de variáveis. É inclusivo que as três possibilidades sejam pensamentos, ainda que cada possibilidade dê uma resposta ao mesmo objeto, qual seja, pensamento.
} 
dade em que o mesmo objeto passa por diferentes circuitos e a cada vez a descrição apaga o objeto ao mesmo tempo que a imagem virtual cria outro, diz Deleuze: "A tal ou qual aspecto da coisa corresponde uma zona de lembranças, de sonhos ou de pensamentos: a cada vez é um plano ou um circuito, de modo que a coisa (o objeto) passa por uma infinidade de planos e circuitos que correspondem a suas próprias 'camadas' ou aspectos" (DELEUZE, 2007, p. 61).No cinema moderno, segue Deleuze: "Não há mais imagens sensório-motoras com seus prolongamentos, mas vínculos circulares mais complexos entre imagens óticas e sonoras puras por um lado, e, por outro, imagens vindas do tempo ou do pensamento, sobre planos coexistentes em direito [...] um circuito fechado que vai do presente ao passado, depois nos traz de volta ao presente" (2007, p.62-63).

FIGURA 2: DESENHO BASEADO NO 1॰ ESQUEMA DE BERGSON SEGUNDO

DELEUZE (DELEUZE, 2007, P. 62)

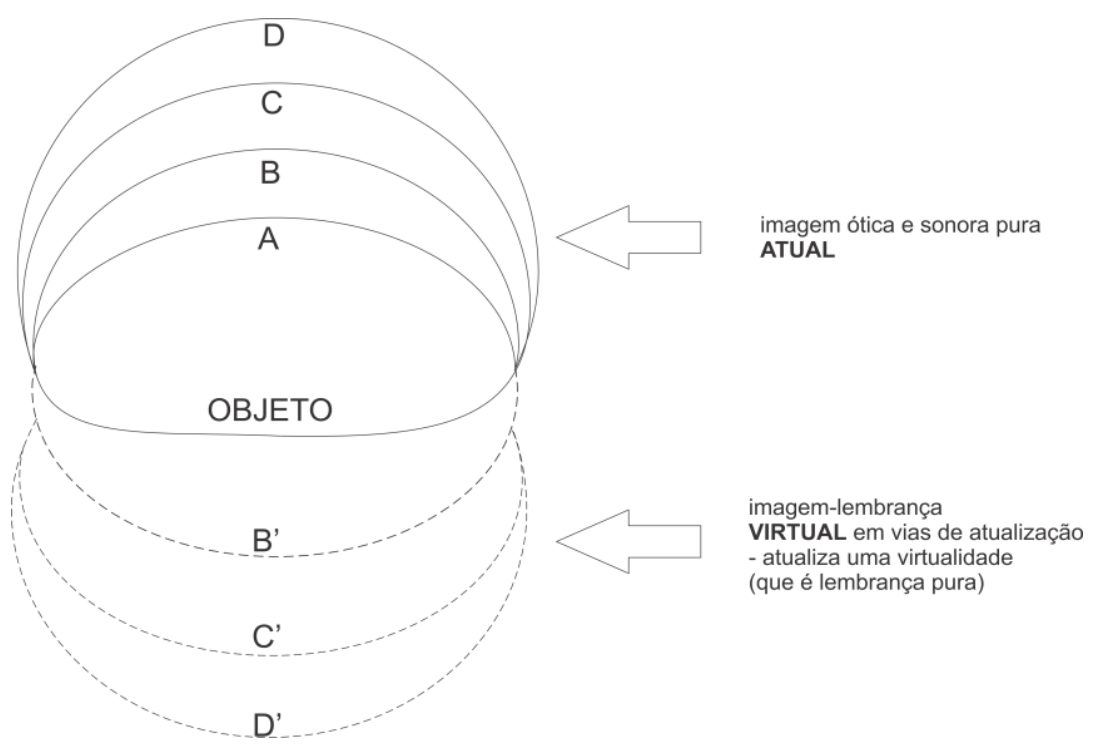


Na imagem-lembrança não há mais a reunião de objetos quantificando-os para extrair semelhanças contíguas, agora essa imagem permanece no mesmo objeto num movimento verticalizado, num movimento de profundidade. A imagem atual não vai se prolongar tão e somente em movimento sucessivo entre as partes, ela formará num encadeamento com a imagem-lembrança um circuito, donde vislumbraremos num mesmo plano um eixo horizontalizado e um eixo verticalizado entrecortados, em outros termos, numa mesma imagem teremos a translação que é espacial e teremos simultaneamente a duração que é temporal.

\section{A PROFUNDIDADE DE CAMPO COMO TÉCNICA FÍLMICA E A SUA NECESSIDADE DA MEMÓRIA}

A profundidade de campo é trazida por Deleuze no capítulo 5"Pontas de presente e lençóis de passado" do livroImagem-tempo como elemento operacional que o permitirá relacionar o cinema enquanto maquinismo de composição de imagens com a noção bergsoniana de passado como movimento não submetido à fragmentação descontínua do tempo. Portanto, a profundidade de campo como o eixo verticalizado da imagem que será tomada como técnica dupla que serve ao cinema e ao pensamento filosófico enquanto liberação do tempo no movimento.

Tecnicamente profundidade de campo é um modo de filmar no qual o plano de fundo, o plano-médio e o primeiro plano de uma tomada estão simultaneamente focados. É a zona de nitidez da imagem. Fecha-se o diafragma e aumenta 
a velocidade da captura, de modo que ao ampliar o campo aumenta-se o número de elementos em foco. A profundidade transforma a bidimensionalidade do cinema em tridimensionalidade na medida em que parece reproduzir o campo de visão do ser humano, ou seja, as linhas internas da imagem serão não apenas de comprimento e largura, nas direções de cima para baixo e de uma lateral à outra, uma terceira linha que é transversal entre o planos insere volume no interior da imagem. Nesse sentido, a utilização da profundidade de campo põe os elementos de cada plano em interação. Há uma comunicação direta entre o primeiro plano e o plano de fundo.

Deleuze ao analisar o uso recorrente da profundidade de campo nos filmes de Orson Welles, observa que espaço e tempo são dilatados e comprimidos alternadamente, sendo que as plongées e contra-plongées formam contrações e os travellings oblíquos laterais formam lençóis de tempo.A profundidade de campo se alimenta nessa exploração das zonas virtuais do passado. É uma figura de temporalização e de memorização ${ }^{11}$. A zona de nitidez(o foco) da profundidade de campo forma diretamente uma região de tempo, uma dimensão que se define pelos planos em interação.

Pois bem, Wöllfliné o autor citado por Deleuzeque apresenta a diferença entre profundidade no campo e profundi-

\footnotetext{
${ }^{11}$ Diz nos David Lapoujade em Potências do tempoque nos remete ao tema da profundidade de campo: "Na profundidade, não somos mais 'seres', mas sim vibrações, efeitos de ressonância, 'tonalidades' de diferentes frequências. E o próprio universo acaba se desmaterializando para se tornar duração, uma pluralidade de ritmos de duração que também se superpõem em profundidade, de acordo com níveis de tensão distintos". [LAPOUJADE, David. Potências do tempo = Powersof time Tradução Hortência Santos Lencastre. São Paulo: n-1 Edição; Aalto, FI: AaltoUniversity, 2012. p. $11]$.
} 
dade de campo ${ }^{12}$ como mudança de concepção no uso da técnica em comparação à pintura do século XVI e à do século XVII.Para o historiador da arte, a profundidade no campo era utilizada por pintores do século XVI enquanto combinação das formas no plano, tendo uma representação no plano que articulava a imagem em camadas dispostas paralelamente à boca da cena ao ponto central do quadro, daí profundidade no campo. Embora a pintura apresentasse mais de um plano, esses planos não se comunicavam, mantinham-se paralelos uns aos outros. De outro modo, a pintura do século XVII traz a profundidade de campo enquanto uma composição notadamente voltada para os efeitos de profundidade, destacando a "tendência a subtrair os planos aos olhos, a desvalorizá-los e torná-los insignificantes, na medida em que são enfatizadas as relações entre os elementos que se dispõem à frente e os que se encontram atrás, e o observador se vê obrigado a penetrar até o fundo do quadro" (WÖLFFLIN, 1986, p. 79). Continua Wölfflin, "a beleza das superfícies planas é substituída pela beleza da profundidade, que está sempre vinculada a uma impressão de movimento" (1986, p. 83). Abaixo temos duas pinturas cujas profundidades analisadas por Wölfflin evidenciam a relação entre os planos, sobretudo quando da distinção entre pintura renascentista e pintura barroca.

\footnotetext{
12 "une profondeur dans l'image ou dans lechamp, et non pas encore une profondeur de champ, une profondeur de l'image". [DELEUZE, Gilles. Cinéma2: L'image-temps. - Paris: Les Éditions de Minuit, 2009, p. 140].
} 

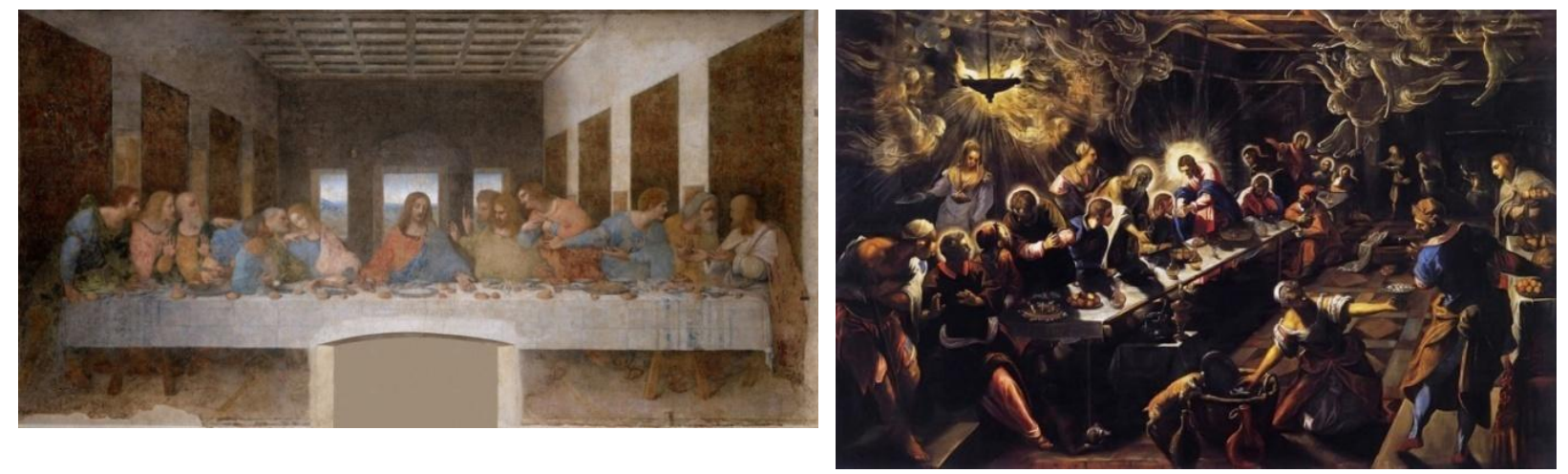

No curso de 24/abril/1984 ${ }^{13}$, Deleuze partindo de Wölfflintrata de dois pintores para abordar a relação entre planos na pintura. A primeira obra citada é "Adão e Eva" de 1550 do italiano Tintorettoe a outra "Adão e Eva" de 1628 do flamengo Rubens, tendo acontecida em ambas a mudança no uso da profundidade de campo. Em Tintoretto, Deleuze descreve a existência de uma diagonal entre o plano de Adão sentadoque se curvapara Eva e que por sua vez está num outro plano. Essa diagonal apresenta uma relação direta entre planos distintos cujo assunto é próprio e respectivo a cada uma das personagens, ou seja, Adão remete a um conjunto de partes dentro do quadro e Eva remete a outro conjunto de partes, entretanto a diagonal coloca os

\footnotetext{
${ }^{13}$ Curso 61 parte 1 de 24/04/1984, publicado em áudio e transcrito por Lucie Picandet em La voix de Gilles Deleuze enligne (Universidade Paris 8).
} 
planos não mais num sentido paralelo e de independência, de modo que no quadro esses planos estão em comunicação ao mostrar que Adão se curva para se dirigir à Eva. $\mathrm{Na}$ sua análise de Tintoretto, percebemos que Deleuze remete em especial à forma, aos contornos das personagens para falar da coexistência dos planos. Em Rubens, em especial, segundo Deleuze, mantém-se a presença dos personagens lado a lado num plano, Adão e Eva, e ainda atrás destes outros personagens lado a lado, anjo e pássaro, entretanto há entre o lado a lado das personagens uma fenda que envolve todos os planos e os impede de se manterem autônomos remetendo aos seus respectivos temas isoladamente. A pintura de Rubens apresenta um cruzamento interno entre os planos ainda que esse cruzamento não seja dado diretamente como no caso de Tintoretto onde Adão se volta para Eva, diversamente, agora a fenda é o cruzamento que envolve os planos de modo a impedir que cada um esteja isolado no interior do quadro.

Figura 5: AdÃo e Eva. Tintoretto (1550) Figura 6:AdÃo E Eva. Rubens 

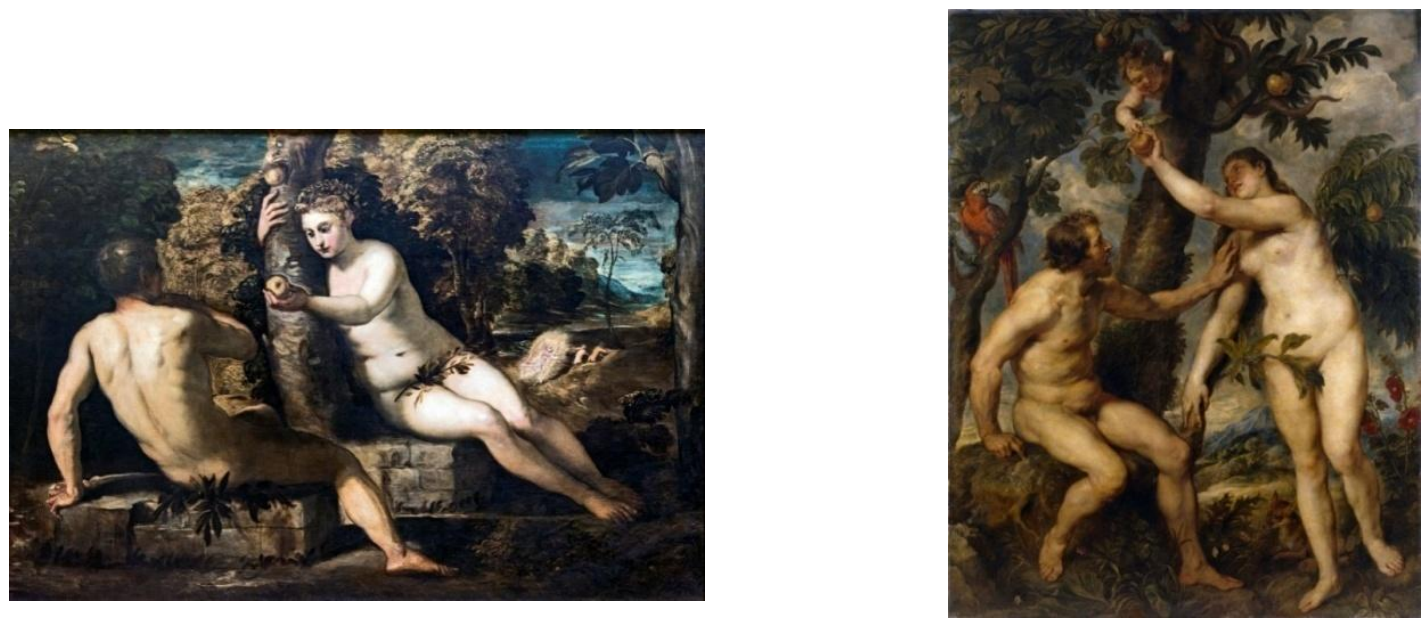

\section{Além da referência à pintura, Deleuze cita dois críticos} franceses de cinema que tratam da profundidade de campo enquanto técnica fílmica, quais sejam: André Bazin e Jean Mitry $^{14}$. Para Deleuze, embora haja traço mínimo de diferença entre ambos ao tratar da profundidade, dois problemassão comuns num e noutro autor ${ }^{15}$ : a novidade do

\footnotetext{
14 "No essencial, o Deleuze cinéfilo é fiel à linha de Bazin: seu panteão homenageia a mesma tríade, Rossellini-Renoir-Welles, e, assim como o pai dos Cahiers, ele vê no neorrealismo italiano o advento do cinema moderno. [...] Ele retomou essencialmente uma história do cinema tal como Langlois, a nouvelle vague, Bazin, os Cahiers, Truffaut e Godard tinham concebido antes dele" (p. 330). [Entrevista com Serge Toubiana. In: DOSSE, François. Gilles Deleuze EG Félix Guattari: biografia cruzada. Trad. Fatima Murad; revisão técnica Maria Carolina dos Santos Rocha. - Porto Alegre: Artmed, 2010. p. 325-344].

${ }^{15} \mathrm{Na}$ nota 15 de rodapé de Imagem-Tempo, Deleuze diz: "O debate Bazin-Mitry tem por objeto os dois problemas. Mas parece que Mitry está bem mais perto de Bazin do que supõe". Nesse sentido, optamos por trabalhar com o texto de Bazin como fonte para entendimento da citação de Deleuze.
} 
procedimento e a função da profundidade.André Bazinno artigoA evolução da linguagem cinematográfica de 1950 para a revista CahiersduCinéma, compreende Orson Welles como o cineasta que apresenta a profundidade de campo como técnica de composição em um plano contínuo. Segundo Bazin até 1938 a montagem dos filmes era realizada como sucessão dos planos marcados por cortes que davam sequência à cena na relação entre campo e contracampo, como na cena de um diálogoem que sefazia a tomada dos personagens seguindo a ordem do diálogo. Por exemplo: personagem $1 \mathrm{fa}-$ la: tomada 1; personagem 2 responde: corta e começa nova tomada 2, ou seja, os planos diferentes e sucessivos. Com o filme Cidadão Kane de 1941, a profundidade de campo em semelhança à mudança apresentada por Wölfflin na pintura do século XVII traz os planos sucessivos para um mesmo plano cuja continuidade da cena é interna. Diz Bazin: "Os efeitos dramáticos, que anteriormente se exigia da montagem, surgem aqui do deslocamento dos atores dentro do enquadramento escolhido de uma vez por todas" (2014, p. 105).Bazin não negligencia que a profundidade de campo estivesse presente na história do cinema antes de Welles, e que este inclusive tenha encontrado em Renoir inovação tal qual a sua, entretanto, antes de Welles e Renoir, a profundidade de campo era produzida enquanto planos paralelos independentes que eram reunidos com vista a um conjunto harmonioso, apontamento este que remete ao que Deleuze trata como profundidade no campo.

Marcel Martin, crítico e historiador francês de cinema, no seu livro A linguagem cinematográfica, ao dedicar um capítulo especificamente para tratar da profundidade de campo 
define esta como uma operação técnica cuja nitidez do campo se estende do primeiro plano ao plano mais ao fundo. Entretanto, no cinema,diferente da fotografia, a filmagem não se dá tão e somente em objetos e elementos que se movem no campo, soma-se também o próprio movimento da câmera que se move.Nesse sentido, Martin evidencia o aspecto estético da profundidade de campo no cinema:

O interesse espetacular do procedimento é, portanto, evidente: mas seu interesse estético não é menor. Ao longo de um travellingóptico (suponhamos um travellingpara a frente), o espectador não tem a impressão (ao contrário do que se passa num travelling comum) de percorrer com a câmera um espaço sólido e indeformável; ele tem a impressão de que o espaço se comprime (por achatamento dos planos uns contra os outros), tornando-se com isso mais denso: de fato, a variação da focal modifica a posição relativa dos planos do espaço entre si (MARTIN, 2003, p. 173).

A função da profundidade aparece em André Bazin, Jean Mitry e em Marcel Martinremetendo à presença da profundidade de campo enquanto um plano-sequência para Bazin, ou plano-síntese para Martin. A funçãodessa técnica, portanto, remete a uma decupagem virtual (diz Martin) que opera unindo na imagem, tempo e espaço (diz Bazin), ou ainda, "o espaço e o tempo constituem um todo homogêneo sucedendo à composição de um espaço indiferente à duração que ele contém, a estruturação de um verdadeiro espaço-tempo. É a duração vivida, essa duração em vias de se fazer" (MITRY, 1963-1965, tomo 2, p. 50-51 apud MARTIN, 2003, p. 174).

Por que une tempo e espaço na mesma imagem? Porque momentos temporalmente distintos sem a profundidade de campo seriam postos na tela um após o outro, mas 
com a profundidade de campo esses momentos são vistos simultaneamente no mesmo quadro; não se trata de sequências montadas a partir de cortes sucessivos que justamente remetem à crítica bergsoniana da reprodução do movimento quantificado, em fato trata de uma montagem interna à própria sequência da imagem.

Num plano-sequênciavemos no quarto três personagens dispostos em posições diferentes na cena. No primeiríssimo plano visualizamos um copo e um veneno, no plano imediatamente seguinte, que é um primeiro plano, visualizamos uma mulher deitada na cama e desacordada. No próximo plano, abre-se um pouco o enquadramento e como num plano quase americano temos um homem assustado com olhar em direção aos dois primeiros planos, o do copo com veneno e o da mulher. Visualizamos ainda um último plano geral com um segundo homem que adentra à cena atrás do primeiro homem que remete ao plano americano. Essa descrição de planos refere-se à cena da tentativa de suicídio de Susan em Cidadão Kane. Acena é destacada pelos críticose também por Deleuze, tendo sidocompreendida como um momento em que Welles utiliza a profundidade de campo para a composição de planos formando um bloco espaçotempo, bem como uma imagem cujas implicações estéticas remetem à duração bergsoniana.

Abaixo dispomos do fotograma da cena do suicídio e de um esquema que evidencia a arquitetura dos planos no interior da cena. Nesse sentido, remetendo à compreensão de Deleuze sobre a profundidade de campo na pintura, aqui percebemos também que a lei de composição não se dá na harmonia dos planos cujos temas são independentes, ao contrário, os planos são atravessados por uma transversal 
que os comunica sem deixar ausentes as duas faces do movimento bergsoniano: translação e duração.

FIGURA 7: FOTOGRAMA DO FILME Cidadão Kane. Orson Welles, 1941

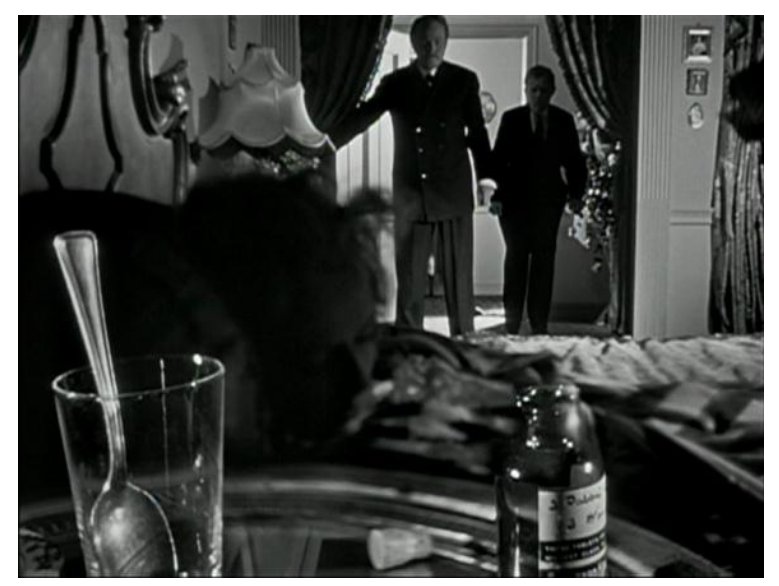

FIGURA 8: ESQUEMA DE PLANOS NO INTERIOR DO QUADRO

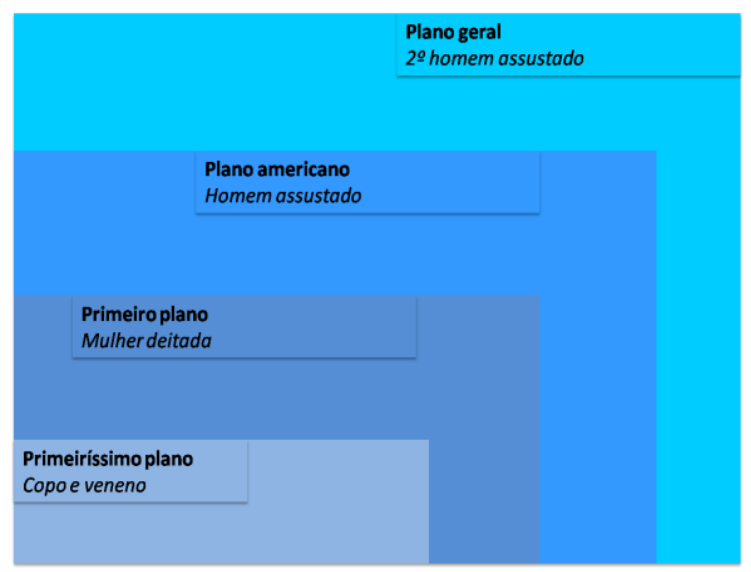

Em Welles encontramos o maquinismo do cinema do tempo operado pelo uso recorrente da profundidade de campo, tendo Deleuze transformado os planos fílmicos em lençóis de passado. Em Cidadão Kane há os três aspectos da metafísica da memória: (i)existência de um passado em geral:um passado de Welles que esclarece sua morte: a palavra Rosebud; (ii)lembrança pura:pontos singulares que serão buscados para serem atualizados nas narrativas sobre $\mathrm{Ka}$ ne;(iii) imagens-lembrança:diante da notícia da morte de Kane são apresentadas narrativas das pessoas que conviveram com ele. "Cada testemunha salta no passado em geral, instala-se de saída nesta ou naquela região coexistente, antes de 
encarnar certos pontos de região numa imagemlembrança”(DELEUZE, 2007, p. 130).

Rosebud aparece duas únicas vezes no filme, no início como uma palavra grafada no trenó do menino Kane, e no final no mesmo trenó sendo lançado à fogueira após a morte do homem Kane. A questão do filme é a investigação pelo vínculo entre a palavra Rosebud e o homem Kane, sendo que cada corte são narrativas das pessoas que descrevem uma face da vida de Kane, seja o mordomo, a ex esposa ou o amigo, de modo que quaisquer das narrativas estão implicadas num Todo que é a vida de Kane.A profundidade de campo tem portanto dupla função em Cidadão Kane. De um modo ela reúne planos que descrevem objetos em seus diferentes desenvolvimentos, por exemplo Susan desacordada ao tentar o suicídio e Kane entrando ao fundo num ímpeto para salvá-la, planos estes que são colocados em um mesmo quadro de apresentação, campo e contra campo,e de outro modo, o tempo é jorrado ao ser apresentado diretamente numa única imagem, a imagem atual e a imagem virtual. $O$ copo de veneno no primeiro plano como um ponto singular da narrativa de Susan, e, Susan desacorda como um ponto singular de Kane em sua empreitada por torná-la uma renomada cantora. O copo de veneno está para Susan na mesma imagem que Susan está para Kane.A imagem tempo direta é essa que não fecha o Todo, ao contrário instala uma questão vertical que aponta para o problema: qual o lençol do passado narrado dentro da imagem resolve a relação entre Rosebud e a vida e a morte de Kane? Questão essa que apenas didaticamente nos insere no problema da imagem cinematográfica, posto que a importância da imagem não se dá na eleição de um representante da si- 
tuação, diversamente, a questão da imagem é justamente dar vistas ao movimento qualitativo que o cinema opera, retomando a compreensão bergsoniana de que os lençóis são movimento da vida de Kane, não cabendo o falso e o verdadeiro, mas sim que o copo de veneno, Susan e Kane são movimentos presentes na contração atualizada na notícia "Kane está morto".

\section{FIGURA 9: ESQUEMA DE RELAÇÕES E PLANOS}
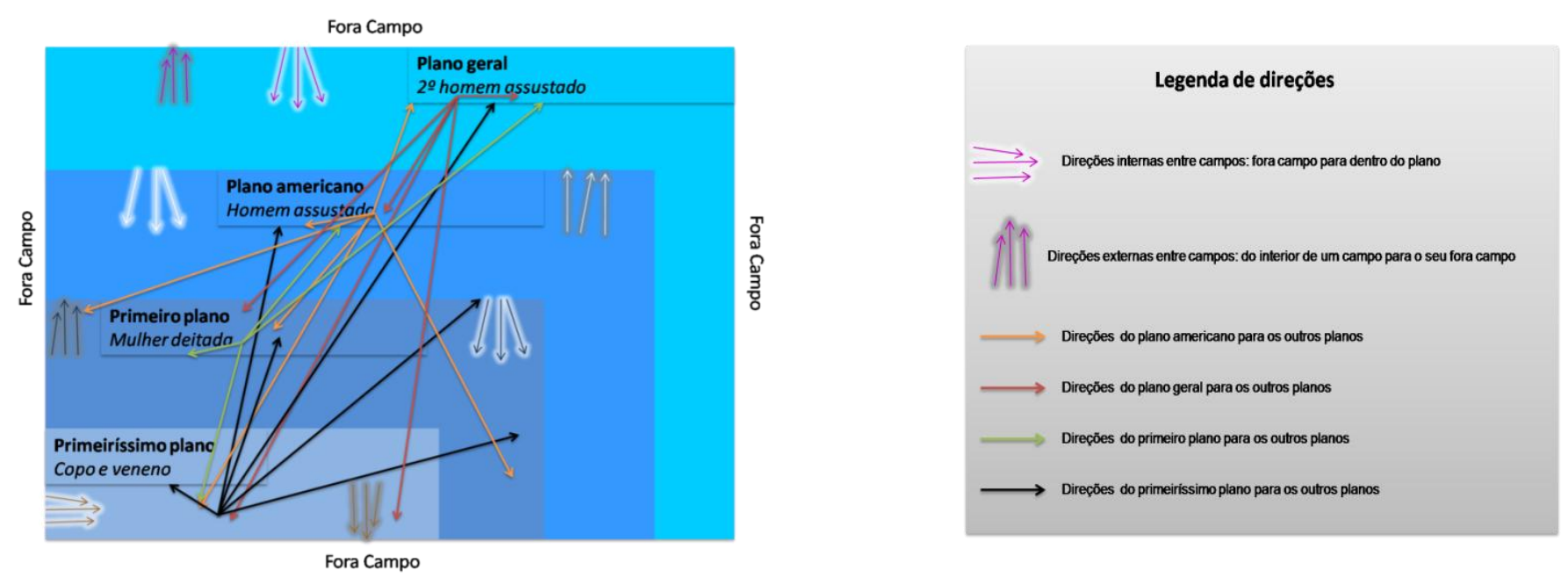

O esquema de relações e planos evidencia a composição dos planos e apresenta a transversal da profundidade de campo. Esta trata do movimento temporal bergsoniano e que Deleuze chama de o emsi da imagem. O quadro trazconjuntos com seus respectivos assuntos e que estão expressos nas personagens e no copo com o veneno, sendo que cada conjunto trata de um plano. Assim temos Susan como um conjunto, o copo e o veneno como outro conjunto, 
Kane como conjunto e o mordomo também como um conjunto. Pois bem, a profundidade de campo como técnica de filmagem nos mostra a comunicação entre os planos, de modo que a leitura filosófica trata cada plano como um lençol de tempo interagindo diretamente na tela de projeção. De outro modo veríamos cenas montadas uma após a outra, dedicadas à mostrar a relação entre conjuntos no mecanismo de ação e reação. Quando Welles coloca os conjuntos no mesmo quadro e os comunica, temos a mutação operada pelo cinema ao inserir movimento na imagem, ele então cria uma imagem tomada pela percepção objetiva deleuziana, que justamente acessa o movimento quando do fluxo espacial e temporal, quando da translação e da duração, eis portanto a metafísica da memória para o cinema do tempo e o cinema do tempo para a metafísica da memória. Welles cria assim um bloco espaço-tempo que traz a vida de Kane e as mudanças qualitativas nelas mesmas, ancoradas pelo anúncio: Kane está morto!

Inicialmente evidenciamos a percepção objetiva que Deleuze recoloca partindo de Bergson e que se faz indispensável para a compreensão do conceito de imagem, pois foi este conceito utilizado como cruzamento para acompanhar o caminho do filósofo que coloca em relação filosofia e cinema. A percepção objetiva nos permite tomar conhecimento da operação que Deleuze realizada ao desantropormofizaro movimento como sendo imanente ao universo e não resultante da percepção natural que mensura o movimento. Nesse sentido, a definição da imagem a partir da percepçãoem Bergson é indispensável para demarcar a diferença da imagem em Deleuze como sendo um regime que se dá justamente na percepção de movimento. 
Apresentamos ainda trêsmomentos buscando principalmente inserir o uso que o autor faz da técnica de profundidade de campo aliada à metafísica da memória de Bergson. Vimos nesse sentido que a profundidade de campo traz os lençóis de passado para uma única imagem, cujo espectador é forçado a pensar a organização dos planos para o entendimento da narrativa, diferentemente do cinema clássico cuja montagem se dá organicamente. Evidenciamos as três teses bergsonianas que fundamentamo percurso de Deleuze ao tratar do cinema, e ainda a problematização do movimento no quarto comentário utilizando a definição de cinema do tempo quetraz à luz os conceitos de atual e virtual, bem como evidencia o maquinismo da imagem cinematográfica do cinema moderno em estreiteza com a teoria da memória bergsoniana. Nesse sentido, vislumbramos que Deleuze opera colando a técnica fílmica de profundidade de campo no seu construto filosófico, pois ao colocar variados planos conectados em um único plano aprofundado como em Welles, Deleuze estaria colocando no seu pensamento a relação horizontalizada entre espaço e tempo, de modo que no espaço do écran cinematográfico a tese filosófica de um passado ontológico estaria atualizada como uma personagem conceitual conectada ao seu maquinismo próprio de constituição, estando a metafísica da memória para o cinema do tempo assim como este para aquela.

De posse da reflexão deleuzeana sobre o cinema, se impõe a nós o questionamento quanto à importância da relação estabelecida entre metafísica da memória e cinema do tempo, em outros termos: Qual a contribuição do pensamento de Deleuze sobre a profundidade de campo para a produção artística cinematográfica? Menos técnico e mais 
estético são os contornos ensaísticos de uma resposta, pois, quando Deleuze diz que o cinema produz imagens que trazem diretamente o tempo, compreendemos que o tempo desde o começo do cinema tenha sido uma das suas matérias primas, e no curso variado das cinematografias revela-se um caráter duplo do tempo como condição de produção artística. Trata de um tempo de medição indispensável quando do processo de criação enquanto composição de técnica de filmagem, ou seja, há um tempo medido e necessariamente quantificado que pontua as etapas de feitura de um filme. No roteiro é indispensável a precisão de um contexto temporal, pois a marcação das personagens no momento em que são filmadas, por exemplo quando de uma cena de choro, o tempo das lágrimas precisa a importância do referido fato no desenvolvimento da personagem.A relação indispensável com a luz se dá na medição do tempo quando da parada e da velocidade de segundos na exposição do aparelho de captação à luz, com o fotômetro o cinema conjuga velocidade do obturador e abertura do diafragma. $\mathrm{O}$ uso do som como paisagem musical é pontualmente trabalhado em conjunto com os momentos do roteiro: há som para o assassinato, há som para a desilusão, som para o casamento, o som inclusive pode anteceder um corte, e não apenas, o som do assassinato sendo temporalmente simultâneo ao desenrolar do fato diz algo, exalta algo, esconde algo, é também a medida da composição do som com a imagem que revela a encenação do roteiro. Esse tempo é o tempo da dimensão técnica do audiovisual, é referência para o realizador de posse de um assunto que deverá decidir por criar o filme em 15 minutos como um curta-metragem ou em 2 horas como um longa-metragem. Aqui lembro o 
caso do longa-metragem de 98 minutos, Não matarás, de 1988 do diretor polonês Kieslowskie que trata de umaversão ampliadado curta-metragem de 58 minutos, Não cometerás adultério, de 1989 produzido para série de televisão. A questão do tempo como dimensão técnica insere variáveis que incidem diretamente nas escolhas estéticas quando da produção, por tal, o tempo como quantidade é indispensável no cinema, pois a escolha por criar um filme com 98 minutos difere diretamente na dinâmica do processo audiviosual quando comparado à criação de um filme com mesmo tema em 58 minutos. A escolha pela extensão temporal das cenas e pela própria quantidade das cenas nos dão a importância do aspecto técnico do tempo. Compreender que o tempo nessa dimensão técnica da produção cinematográfica mostra o caráter de uma arte que se faz também a partir de dispositivos modernos, que tem em si um processo mecânico de criação de imagens, já que o cinema é filho de invenções modernas, em termos de técnica na relação com a luz e ainda em termos de tecnologia no uso de máquinas de captação de imagem e de som, bem como máquinas de montagem e estratégias de exibição e circulação dos filmes.

Pois bem, mas o cinema não se contenta tão somente com o tempo técnico, ele ousa torcer o tempo no próprio uso da dimensão técnica. Ora, essa torção do tempo é um salto que faz com que o cinema não se limite ao fracionamento dos segundos nas ilhas de edição ao mesmo tempo quenecessitadesse mesmo fracionamento. Deleuze portanto ao falar em cinema do tempo torna evidente um tempo cinematográfico que não nega o tempo de medição técnica na criação e que desta é dependente, mas nela não se encer- 
ra. Nesse sentido, o tempo no cinema tratado por Deleuze com o uso da profundidade de campo é um tempo duplo, técnico e metafísico, e assim o é porque extrapola a imagem vista sem dela sair.

A pintura barroca foi a arte que Deleuze evocou para inserir a profundidade de campo no quadro destacando a relação entre os planos, mas, foi o cinema que valendo-se da profundidade de campo coloca em comunicação direta os planos no quadro, permite que o fora do quadro também esteja presente na relação dos planos.A diagonal entre os planos no quadro é a que extrapolando o próprio quadro movimenta-se num fluxo de entrada e saída de planos, trazendo inclusive o extra-campo e a voz off como presenças, que embora estejam num plano invisível inserem-se como partes do movimento da imagem. Assim, encontramos na profundidade de campo o cinema do tempo compondo planos visíveis e também planos invisíveis a partir de uma transversal que remete diretamente ao movimento de duração bergsoniano. No movimento de translação vemos as partes de cada plano e no movimento de mudança percebemo-lo enquanto movimento porque ao ser continuamente aberto está em relação com os planos que vemos e também com os planos que não vemos mas que se insistem na imagem. Rosebaud em Cidadão Kane quiçá tenha sido o extra campo recorrentemente presente nas imagens de Welles.

Distante do objetivo de estabelecer um inventário da nobreza teórica dos dois livros sobre cinema, compreendemos que Deleuze estabelece um diálogo com o cinema demarcando sobretudo o modo como as imagens em movimento inserem-se, constitutivamente, no pensamento 
abrindo frestas para uma lógica da sensibilidade que não dissocia alma e corpo, forma e matéria. Deleuze nos mostra a possibilidade de um duplo percurso, onde cinema pensa e onde filosofia faz cinema, pois ao levar a percepção para as coisas mesmas, estaria retirando a primazia do sujeito diante das noções de tempo e espaço, ambos existindo para além do sujeito como condições de diversidade das imagens, noutros termos: tempo e espaço como condições imanentes ao cinema e ao pensamento. Assim posto, entendemos que Deleuze se vale de Bergson como caixa de ferramentas fundamentais para o seu diálogo com a sétima arte, e não apenas, outras alianças são assumidas por Deleuze na sua arquitetônica, nomes como Pierce evidentemente apresentado na introdução de Cinema 1, e ainda, Kant que possibilitará a reviravolta ao pensar as condições dos fenômenos, e também para Deleuze, pensar as condições do pensamento cinematográfico. Cabe-nos desdobrar a analítica deleuzeana da profundidade de campo como técnica dorsal de um cinema do tempo e perguntarmos, portanto, pela profundidade de campo no pensamento e as imagens por este criadas. Se temos, em face da arte das imagens em movimento, o cinema do tempo composto com a metafísica da memória, quais são os pensamentos que em composição com os falsos raccords, profundidade de campo e personagens perambulantes, teríamos na história da filosofia? Em outros termos: Qual pensamento em profundidade focada compõe temporalidades qualitativas? Eis o desdobramento deleuzeano de movimento ininterruptodemandando porimagens de pensamento. 


\begin{abstract}
In The Time-Image, Deleuze comments on the concept of the image in Bergson's work and introduces the concept of " a cinema of time " in reference to Orson Welles and the film Citizen Kane. The cinema of time is presented by Deleuze as having three characteristics of non-chronological time. Moreover, Deleuze argues that a necessary condition of a cinema of time is the replacement of a longitudinal pragmatic view by an optical and vertical vision characterised by depth. In Deleuze's dialogue with modern cinema, depth of field becomes a conceptual element in his reading of the metaphysics of memory in Bergson's work. Thus, the three characteristics of non-chronological time and the advent of a new relationship between time and space in cinema have given rise to a direct time-image where the philosophical problem of the insertion of movement in thinking can be observed. The meeting and interplay of Deleuze's fourth commentary in The TimeImage with his first commentary on Bergson in The Movement-Image enable us to understand the importance of depth of field. Hence, Welles' cinema of time film is understood by Deleuze as a metaphysics of memory for two reasons : the effort required in the present in order to evoke the recollectionimage and the utilisation of the virtual zones of the past in order to find the recollection-image.
\end{abstract}

Keywords: cinema, time, Deleuze, depth of field, Bergson.

\title{
BIBLIOGRAFIA
}

DELEUZE, Gilles. Cinéma1: L'image-mouvement. Paris: Les Éditions de Minuit, 2015.

. Cinéma2: L'image-temps. Paris: Les Éditions de Minuit, 2009.

. Cinema 1: A imagem-movimento. Tradução de Stella Senra. São Paulo: Brasiliense, 1985.

. Cinema 2: A imagem-tempo. Tradução de Eloisa de Araujo Ribeiro. São Paulo: Brasiliense, 2007.

. Bergsonismo. Tradução de Luiz B. Orlandi. São Paulo: Ed. 34, 2008a.

. Conversações. Tradução de Peter PálPelbart. São 
Paulo: Ed. 34, 2008b.

AUMONT, Jacques. A imagem. Tradução de Estela dos Santos Abreu, Cláudio C. Santoro. São Paulo: Papirus, 2012.

BAZIN, André. A evolução da linguagem cinematográfica. In: $O$ que é Cinema?. Tradução Eloisa Araújo Ribeiro. São Paulo: Cosac Naify, 2014.

BELLOUR, Raymond. Pensar, contar. O cinema de Gilles Deleuze. In: Cinema/Deleuze. André Parente (org.). São Paulo: Papirus, 2013, p. 233-248.

BERGSON, Henri. Matéria e memória: ensaio sobre a relação do corpo com o espírito. Tradução de Paulo Neves. $4^{\mathrm{a}}$ ed. São Paulo: Martins Fontes, 2010.

. A evolução criadora. Tradução de Bento Prado Neto. São Paulo: Martins Fontes, 2005.

DOSSE, François. Gilles Deleuze \& Félix Guattari: biografia cruzada. Tradução de Fatima Murad. Porto Alegre: Artmed, 2010.

LAPOUJADE, David. Potências do tempo $=$ Powersof $t i-$ me. Tradução de Hortência Santos Lencastre. São Paulo: Aalto University, 2012.

MARTIN, Marcel. A linguagem cinematográfica. Tradução Paulo Neves. Revisão. São Paulo: Brasiliense, 2003.

- A linguagem cinematográfica. Tradução de Paulo Neves. São Paulo: Brasiliense, 2003, p. 174.

MONTEBELLO, Pierre. Deleuze, philosophieetcinéma. 
Paris: Libraire Philosophique J. Vrin, 2016.

PAMART, Jean-Michel. Deleuze et lecinéma: l'armature philosophique des livres sur le cinéma. Paris: Éditions Kimé, 2012.

WÖLFFLIN, Heinrich. Conceitos fundamentais da história da arte: o problema dos estilos na arte mais recente. Tradução de Marion Fleischer. São Paulo: Martins Fontes, 1986. 